Владимир Труб

Институт украинского языка НАН Украины, Киев Отдел социолингвистики
trub44@ 9 ukr.net УДК $811.161 .1 ' 367.62437$
https://doi.org/10.18485/slavistika.2019.23.1.3 оригина примљено 14.05 .2019 прихваћено за штампу 16.05.2019.

\section{К ПРОБЛЕМЕ ВЫЯВЛЕНИЯ ВИДОВЫХ ГЛАГОЛЬНЫХ ЗНАЧЕНИЙ, СВЯЗАННЫХ С УПОТРЕБЛЕНИЕМ АДВЕРБИАЛОВ}

Работа основывается на положении о том, что широкий спектр видовых значений совершенного и несовершенного вида (СВ и НСВ) свойственен не только глаголам (и - шире - вербоидам) как главным носителям аспектуальных значений, но на эти значения могут опосредованно указывать ряд невербоидных частей речи, не имеющих каких-либо формальных аспектуальных показателей. Вместе с тем значение многих из них опосредованно связано с предикатами, нормативно обозначаемых глаголами. К таким неглагольным языковым единицам - носителям имплицитных аспектуальных значений - относятся, в частности, адвербиалы - наречия или группы, образуемые сочетанием предлогов или союзов с существительными. В работе рассматриваются различные типы аспектуальных значений, связанных с употреблением адвербиалов.

Ключевые слова: совершенный вид, несовершенный вид, адвербиал, валентность, глагол, предикат, видовое значение, актуально-длительное значение, итеративное значение, событийное значение.

The article is based on the statement that a great deal of aspectual meanings of the perfective and imperfective aspect is intrinsic not only to verbs, as the main carriers of aspectual meanings, but also to mperfective is bect in a number of non-verbal parts of speech without any formal aspectual a of many of those non-verbal units is indirectly connected with predicates which are normally indicate with verbs. Among those linguistic units with implicit aspectual meanings there are, in particular adverbials - the adverbs or phrases formed with a combination of prepositions or conjunctions with nouns. The article deals with different aspectual meanings arising in cases when adverbials are used.

Key words: perfective aspect, imperfective aspect, adverbial, valence, verb, predicate, aspectual meaning, actually lasting meaning, iterative meaning, event-trigger meaning.

Как известно, в славянских языках любой глагол не может не быть носителем той или иной видовой грамматической формы. Для семантического анализа существенно то, какие конкретные видовые значения глагола в каждом случае реализуют граммемы «СВ» и «НСВ». Следует иметь в виду, что видовые значения проявляют себя в аспектуально однозначном контексте. На уровне парадигматики (например, в словаре) конкретное видовое значение глагола часто не может быть выявлено. На парадигматическом уровне такое значение может быть установлено, если соответствующая видовая форма нормативно используется для выражения видового значения, свойственного семантическому типу предикатов (Булыгина 1982) или акциональному классу (Храковский 2018), к которому относится данный глагол.

Если же подобная согласованность видовой формы с соответствующим ей акциональным классом отсутствует (например, если в словаре в форме НСВ зафиксирован «моментальный» глагол или глагол, заведомо не имеющий акту-
К проблеме выявления видовых глагольныхх значений.

ально-длительного значения), то тогда о конкретном видовом значении глагола нельзя сказать ничего определённого. Такие употребления можно условно уподобить глагольным формам в языках, в которых вообще отсутствует грамматический вид и значение глагола предстаёт в «чистом виде», не отягощённом какой-либо видовой спецификой.

Это же относится не только к глаголам как к главным носителям грамматического видового значения, но и к ряду не вербоидных частей речи, не имеющих каких-либо формальных аспектуальных показателей, однако семантика которых опосредованно связана с предикатами, нормативно обозначаемых глаголами. К таким неглагольным языковым единицам - носителям имплицитных аспектуальных значений - относятся прежде всего отглагольные существительные (ср. (Пчелинцева 2016, Труб 2015))1, некоторые прилагательные, а также адвербиалы - наречия или группы, образующие сочетания предлогов или союзов с существительными - ср. по ошибке, по мнению, под влиянием, по сове$m y$, в поисках и т.д. Имеется в виду употребление таких групп в синтаксической функции обстоятельства в отличие от случаев их использования как компонентов именного сказуемого - ср. быть под влиянием, быть (находиться) под контролем, быть в (постоянных) поисках и т.д.

Как известно, на уровне синтаксической структуры предложения адвербиал, примыкаюший к глаголу, рассматривается как единица, подчинённая глаголу. В то же время с точки зрения логико-семантического представления фразы глагол так или иначе заполняет пассивную семантическую валентность адвербиала, т.е. валентность, которая заполняется словом, синтаксически подчиняющим данный адвербиал, выступая в качестве его семантического актанта (Богуславский 2008). В первую очередь нас будут интересовать различные типы аспектуальных значений, связанные с употреблением адвербиалов, производных от глаголов. Поскольку эти производные единицы соотносятся с той же ситуацией, что и производящий глагол, их семантический тип как правило совпадает с акциональным классом, к которому относится производящий глагол. При этом, в отличие от глаголов, они не являются носителями какого-либо грамматического видового значения. Однако на уровне синтагматики, т.е. будучи употреблены в рамках какого-либо предложения, создающего аспектуально однозначный контекст, они способны указывать на то конкретное видовое значение производящего глагола, которое имеется в виду в рассматриваемой фразе.

Можно выделить по крайней мере два основных типа таких употреблений: адвербиал является предикатом, так или иначе производным от некоторого глагола (I) или же адвербиал является самостоятельным полноценным предикатом, валентность которого заполняется глагольным сказуемым (II).

I. Адвербиал является альтернативным способом выражения того или иного глагольного предиката. В подобных ситуациях задача анализа состоит в выявлении видового значения глагола, «замаскированного» под адвербиал. Для этого

${ }^{1}$ Как было показано в монографии (Пчелинцева 2016) грамматическое видовое значение очень ограниченно проявляется у русских отглагольных существительных, но охватывает значительное количество существительных украинских и приобретает практически регулярный характер в польском языке. 
следует преобразовывать анализируемую фразу в такое синонимичное ей выражение, в котором данный глагольный предикат фигурирует в явном виде. Искомое видовое значение существенно зависит от семантического типа предиката, с которым соотносится адвербиал, а также от видовой формы глагольного сказуемого.

1. Рассмотрим для начала наречие неправильно, которое в терминах теории лексических функций (Жолковский, Мельчук 1967) квалифицируется как замена $\mathrm{Adv}_{2}$ по отношению к глаголу ошибаться (т.е употребление наречия приводит к превращению второго актанта данного предиката в глагольное сказуемое):

\section{(1) Он неправильно выбрал средства = (1а) Он оиибся в выборе средств;}

(2) Он неправильно подвёл баланс $=(2 \mathrm{a})$ Он ошибся в подведении баланса

Как видим, в $(1 \mathrm{a}-2 \mathrm{a})$, в которых значение $(1-2)$ представлено более эксплицитно, содержится глагол ошибаться, употреблённый в форме СВ. Выбор формы СВ этого глагола в данном случае предопределён формами СВ глаголов выбирать в (1) и подводить в (2), т.е. видовой формой семантических актантов наречия неправильно. При этом в $(1-2 \mathrm{a})$ речь идёт об однократной завершённой акции, которая квалифицируется как ошибочная.

На глубинном уровне ошибочная деятельность может быть проинтерпретирована посредством структуры 'вместо $\mathrm{P}, \mathrm{Q}$ ', в основе которой лежит универсальная формула противопоставительного отрицания 'не $\mathrm{P}$, a Q'. Важная особенность глагола ошибаться состоит в том, что он допускает по крайней мере два альтернативных варианта модели управления его предикатным актантом:

- то ли в виде отглагольного существительного или именной группы в предл. падеже;

- то ли в виде деепричастного оборота.

Реализация первого варианта модели управления делает невозможным конкретное, прямое указание ошибочного действия Q. Адвербиал неправильно соотносится с такой формой глагола ошибаться, которая допускает только первый вариант модели управления. Поэтому конкретный характер действия Q остаётся не уточнённым. Так, в ( 1 - 2a) обозначена только цель деятельности, в которой была допущена ошибка (выбор средств, подведение баланса), но никак не конкретное действие, повлёкшее за собой эту ошибку.

В то же время адвербиал по ошибке соотносится с формой ошибаться, допускающей только второй вариант модели управления. При этом на поверхность выносится прямое обозначение действия Q:

(3) Власти арестовали его по ошибке = (3а) Власти ошиблись, арестовав его,

(4) Хочется верить, что гость из прошлого заглянул сюда по ошибке = (4a) Хочется верить, что гость из прошлого ошибся, заглянув сюда.

Рассмотрим ещё ряд адвербиалов типа $\mathrm{Adv}_{2}$.

2. (5) Под его контролем проходило реформирование финансового регулирования = (5a) Он контролировал реформирование финансового регулирования;

(6) Под его контролем мина была обезврежена прямо в двориовом парке = (6а) Он проконтролировал обезвреживание мины прямо в двориовом парке;
(7) В отместку забытая Альдонса показывает рыиарю Дульсинеи обратную сторону жизни (рыцарь везде натыкается)= (7а) Забытая Альдонса мстит рыщарю Дульсинеи, показывая ему обратную сторону жсизни (рыцарь везде натыкается);

(8) В отместку он написал отрицательный отзыв на её книгу = (8a) Он отомстил ей тем, что написал отрицательный отзыв на её книгу

В приведенных примерах (5a), (6a), (7a), (8a) видовая форма предикатов контролировать, мстить предопределена видовой формой их семантических актантов в (5), (6), (7), (8). В (5а) форма НСВ контролировал реализует процессное значение $\mathrm{HCB}$, характеризующее процесс контроля «изнутри»- в период между его началом и завершением. В (6а) форма СВ проконтролировал имеет событийное значение, указывая на завершённый однократный процесс контроля. В (7a) форма НСВ мстит употреблена в итеративном значении, указывая на многократные акты мести, в результате которых «рыцарь везде натыкается». А в (8а) форма СВ отомстил реализует событийное значение.

3. Адвербиал во избежание Р предусматривает, что в предложении, в котором он фигурирует, сказуемое обозначает меры, принятые (или которые следует принять), чтобы не имела места ситуация Р, обозначенная подчинённым существительным в род. падеже или соответствующей именной группой. Тем самым данный адвербиал эквивалентен целевому обороту с иелью (чтобы) избежать (избегать) Р. При этом задача семантического анализа состоит в том, чтобы установить, какая видовая форма глагола (избежать или избегать) скрывается за адвербиалом. В данном случае противопоставление видовых форм сказуемого маркирует соответственно однократность или же узуальность нереализации ситуации $P$.

В пользу первой (однократной) интерпретации свидетельствует употребление глагольного сказуемого в форме СВ:

(9) И тогда наша 21-я армия была вынуждена во избежание окружения отступить на юг к Десне. Полковник Емышев от огорчения украл двести казённых рублей, но пойманный с поличным вынужден был их вернуть и уйти с работы во избежание более серьёзных последствий (НКРЯ).

И наоборот, узуальная интерпретация диагностируется в случае употребления сказуемого в форме НСВ:

(10) Во избежание неприятных ситуаций трансляция с мероприятий Олимпиады велась с задержкой в несколько секунд. Во избежание конфликтных ситуаций те, которые сидят в одной камере, должны как-то совмещаться друг с другом психологически. Власти Иркутска ежегодно накануне Пасхи обрабатывали яйцо воском во избежание его окрашивания, так как у иркутян появилась традиция красить памятник перед церковным праздником (НКРЯ).

В последнем примере форма НСВ обрабатывали закономерно подкрепляется оборотом ежегодно накануне Пасхи, который употребим только в сочетании с глаголом НСВ.

Кроме того на неоднократную трактовку указывают предложения, сформулированные в виде правил, инструкций, которые всякий раз следует неукосни- 
тельно выполнять. Правила адресуются любому их потенциальному исполнителю, обозначение которого обычно отсутствует:

(11) Во избежание деформации пластмассовых деталей соковыжималки не мойте их горячей водой и не кладите на горячую плиту. В течение всего времени консервации дверь шкафа держать приоткрытой во избежание появления запаха в камере (НКРЯ).

Примечательно, что при формулировании правил требование употребления сказуемого в форме НСВ не является жестким:

(12) Во избежание отравления собирать грибы только в жёсткую проветриваемую тару; переработать собранные грибы в день сбора (НКРЯ),

где форма СВ инфинитива переработать, конечно, указывает на многократность.

4. Адвербиал по словам $X$ - $a$ соотносится с ранее состоявшимся речевым действием, нормативно обозначаемым глаголом СВ:

(13) По его словам, этого следовало ожидать = (13a) Он сказал, что этого следовало ожидать.

Заметим, что (13) может быть представлено и как (13б) Он говорил, что этого следовало ожидать, которое не исключает и итеративной интерпретации НСВ говорил. Отсюда следует, что (13) не имеет абсолютно однозначной аспектуальной интерпретации. Но такая однозначная интерпретация, очевидно, не была предусмотрена и самим говорящим - автором (13). Естественно, что поиск интерпретации, более точной, чем та, что была задумана говорящим, не должен входить и в задачи семантического анализа.

Это же верно и для адвербиала по утверждению, указывающего на ранее состоявшийся акт передачи информации:

(14) По утверждению биологов, найденные кости принадлежат крупному оленю $=(14 \mathrm{a})$ Биологи утверждают, что найденные кости принадлежат крупному оленю.

При этом речь может идти как об однократном речевом действии (если биологи выступают в качестве единого множественного субъекта утверждения), так и о разных одинаковых утверждениях (если биологи высказывались по отдельности). Особенность адвербиала по утверждению, как и соответствующего ему глагола, не имеющего параллельной формы СB, состоит в указании на то, что переданная информация продолжает сохранять актуальность для говорящего и слушающего или для более широкого круга заинтересованных лиц.

Аналогичным образом с завершёнными актами передачи информации, которые нормативно кодируются глагольными формами $\mathrm{CB}$, соотносятся адвербиалы типа по совету, по приказу, по приглашению. В терминах ЛФ они классифицируются как замены типа Adv Perf Real, которые указывают на реализацию идеи, требования, содержащихся в значении ключевого слова - совета, приказа, приглашения - о том, что кто-то последовал совету, выполнил приказ, воспользовался приглашением:

(15) а. В 90-м по приглашению Раисы Горбачёвой Хоген побывала в Москве на фестивале Женщины Гамбурга; б. Уоллис по приглашению королевы останавливалась в Букингемском дворце; в. Как у нас принято, по приказу
Министерства культуры был создан оргкомитет, куда вошли профессор, важные чиновники, начальники; г. Ночью по приказу командарма вся наша оборона ушла в порт грузиться на корабль; д. По совету мамы я впервые в жизни посмотрела этот прекрасный фильм в чёрно-белом варианте; е. В Кривоколенном переулке ... помещалась редакция первого советского толстого журнала «Красная новь», основанного по совету самого Ленина; (НКРЯ).

Тем самым имеется в виду, что ранее состоялся речевой или письменный перформативный акт приглашения, приказа, совета, которым в глубинной структуре нормативно обозначаются глагольными формами СВ в событийном значении: 'Раиса Горбачёва пригласила Хаген в Москву', 'Королева пригласила Уоллис в Букингемский дворец’, ‘Министерство культуры приказало создать оргкомитет', 'Командарм приказал обороне грузиться на корабль', 'Мама посоветовала дочери посмотреть «17 мгновений весны» в чёрно-белом варианте', ‘Ленин посоветовал основать журнал «Красная новь».

Конечно, можно не исключать, что в отличие от приказа, который отдаётся один раз, приглашение или совет могли звучать неоднократно или же имели место в прошлом, находящимся за пределами «времени говорящего» (Апресян 1986). Но на этих возможных альтернативах не заостряет внимания сам говорящий. Более того, они могут быть неизвестны даже ему. Для него важно лишь сообщить, что и приглашение, и приказ, и совет, о которых сообщается впервые, были уже однократно реализованы.

4. Адвербиалы по-моему, по мнению $X$ - $a$ отражают ментальное состояние говорящего или другого лица, нормативно обозначаемое путативными глаголами типа думать, считать, полагать:

(16) По-моему, он неправ = (16а) Я думаю, что он неправ;

(17) По мнению знатоков, осетровые рыбы утратили свой былой вкус $=(17 \mathrm{a})$ Знатоки считают, что осетровые рыбы утратили свой былой вкус.

На ментальное состояние, закономерно обозначаемое формой НСВ надеяться, указывает и адвербиал в надежде, с той лишь разницей, что в его значение входит дополнительный причинный компонент. При этом субъект надежды кореферентен субъекту действия, обозначенного сказуемым:

(18) В надежде найти защиту для «Известий» я не без труда добился встречи c Чубайсом = (18a) Я не без труда добился встречи с Чубайсом, поскольку надеялся найти защиту для «Известий».

Как видим, видовые формы глагольных сказуемых, к которым примыкают адвербиалы, никак не влияют на аспектуальные свойства предикатов мнения. Для передачи ментальных состояний используются формы НСВ.

5. Адвербиал под влиянием в терминах системы ЛФ естественно интерпретировать как замену Adv4 от глагола влиять. Этот адвербиал предусматривает, что в качестве глагольного сказуемого, к которому он примыкает, выступает 4-й семантический актант предиката влиять. При определённых условиях данный предикат допускает четыре семантических актанта:

1) агент влияния (19a-19д);

2) объект влияния (19a-19б); 
3) сфера функционирования объекта, испытывающая воздействие агента (19в-19д);

4) конкретные изменения в сфере функционирования объекта, вызванные воздействием агента.

Важно отметить, что в стандартной модели управления глагола НСВ влиять реализация валентности, соответствующей последнему (четвёртому) актанту затруднена. Данная модель предусматривает, что в качестве второго синтаксического актанта, выражаемого предложно-падежной формой на + Nвин., нормативно реализуются несоподчинимые валентности то ли объекта, то ли сферы его функционирования. При этом речь идёт как правило об общих закономерностях, свойственных нереферентным объектам:

(19) а. Номофобия - боязнь остаться без мобильного телефона - активно влияет на жителей развитых стран, приём чаще женщин, а не мужчин; б. Немаловажный фактор, который влияет на спрос - удобство предоставления оборудования в аренду; в. Слишком яркий свет ... влияет на смену в организме ритмов сон / бодрствование; г. Занятие музыкой влияет на скорость и точность работы нервных клеток; д. Добавление в диету омега-3 кислот не влияет на смертность и не снижает процент инфарктов. [НКРЯ].

Семантическая специфика предиката влиять состоит, в частности, в том, что он указывает на воздействие, которое всегда приводит к какому-то результату. Этим он отличается от глагола воздействовать, в значении которого (в отличие от адвербиала под воздействием) ничего не сообщается о том, насколько это воздействие результативно. В самом первом приближении различие между значениями этих глаголов может быть представлено следующим образом:

влиять $(X, Y) \approx$ 'Caus $\{$ воздействовать $(\mathrm{X}, \mathrm{У}), \mathrm{P}(\mathrm{У})\}$ ', т. е. 'воздействие $\mathrm{X}$-а на У каузирует $\mathrm{P}(\mathrm{У})$ ', где $\mathrm{P}$ - изменение, происходящее с У-ком.

Значение результативности воздействия, описываемое глаголом влиять, сохраняется в значениях всех его частеречных производных (ср. $\mathrm{S}_{0}$ влияние, A влиятельный, Adv под влиянием). В то же время, как было отмечено, у глагола воздействовать такое «результативное» приращение возникает только в значении адвербиальной формы $\mathrm{Adv}_{4}$ под воздействием. Поэтому в ряде контекстов эти адвербиалы могут употребляться как синонимы - например, тогда, когда речь идёт о продолжительном воздействии стихийного неуправляемого фактора на лишённые какого-либо сознания элементы природной среды:

(20) Под воздействием зимних холодов вода этого озера превращается в лёд, а под влиянием летней жары - в соль. ...Нынешнее глобальное потепление вызвано изменениями потоков космических лучей под влиянием изменений солнечной активности [НКРЯ].

Подобные ситуации правомерно рассматривать как реализацию непосредственной причинно-следственной зависимости: зимние холода каузируют превращение воды озера в лёд, а летняя жара - в соль, изменение солнечной активности каузирует изменение потоков космических лучей. В глубинных структурах этих примеров реализуется процессное значение имплицитных форм НСВ глаголов воздействовать, влиять, указывающее на бесконечный процесс результативного воздействия.
К проблеме выявления видовых глагольныхх значений.

Однако в подавляющем большинстве употреблений глагол влиять, в отличие от воздействовать, описывает не непосредственную, а опосредованную каузацию изменений в объекте, обладающем разумом и сознанием. При этом в качестве промежуточного каузатора выступает ментальная сфера объекта Семантические функции адвербиала под влиянием могут варьироваться в зависимости от типов агента влияния и его объекта, а также от того, является ли описываемое взаимодействие целенаправленным. Выделяются следующие типы взаимодействий:

1) И агент, и объект влияния - это лица или некоторые инстанции. При этом агент X целенаправленно воздействует на ментальную сферу объекта У, в результате чего У самостоятельно принимает решение о переходе на тот или иной вид поведения:

(21) Под влиянием московского адвоката Игоря Жигачёва и в сговоре с ним братья решили присвоить огромные суммы денег и имущество своего отца, тем самым лишив младшую дочь г-на Захарова её имущественных прав. Под влиянием педагогического таланта Бартельса Лобачевский вновь увлёкся физикоматематическими науками. После смерти родителя Афанасий под влиянием с протекцией шурина - ротмистра князя И.В.Волконского - поступает на военную службу унтер-офицером в гусарский полк 9НКРЯ).

2) Агент $X$ представляет собой некоторый произвольный, в том числе и ментальный фактор, оказывающий нецеленаправленное, но результативное воздействие на ментальную сферу лица или представительной группы лиц У, что приводит к определённым изменениям в дальнейшем функционировании У-ка. Ср., например, влияние учения Маркса на различные политические и экономические круги в период, когда Маркса уже давно не было в живых, а также:

(22) Итак, я читала «Коварство и любовь» и под влиянием пьесы была совершенно, увлечена и одушевлена ею... Если отвлечься от идеологии, то тот же Степан Бандера пришёл к своим идеям украинского освобождения под влиянием тех же факторов: притеснение украинского языка и культуры. Произведение вроде бы закончено, герой умер, но под влиянием читательского мнения Артур Конан Дойл оживляет Шерлока Холмса и произведение продолжается (НКРЯ).

В глубинных структурах приведенных примеров фигурируют формы СВ повлиять, указывающие на целенаправленную (21) и нецеленаправленную (22) каузацию различных ситуаций. Такие же значения реализуются соответ ственно в примерах $(23-24)$, где форма СВ повлиять фигурирует в поверхностной структуре:

(23)...Режиссёр повлиял на то, что сценарий, который писали полгода, менялся примерно 30 раз, хотя сами съёмки длились чуть больше месяца. То есть это дед повлиял на то, что ты стал художником? (НКРЯ).

Ту же роль могут выполнять и разнообразные факторы - свойства, события, явления:

(24) Его профессионализм повлиял на то, что он пошёл в правительство ДНР. В товарищеском матче с Камеруном он сыграл довольно-таки неплохо, и этот косвенный показатель повлиял на то, что Алан вышел в стартовом составе. Этот фактор, наверное, повлиял на то, что красно-белые до последнего мо- 
мента боролись за золото. Не только лето, но и кризис повлиял на то, что всё больше москвичей стали ставить квартирные счётчики (НКРЯ).

В других случаях в глубинных структурах фигурирует форма НСВ влиять с прототипическим значением итеративной каузации однотипных ситуаций:

(25) Музейная мебель не подвергается искажениям, но мебель из частных собраний, иногда под влиянием заказчика, нередко переделывают, трансформируют, чтобы сделать её боле практичной или привлекательной (НКРЯ).

Примечательно, что в данном примере обозначение агента влияния (заказчика) имеет нереферентный статус и вполне может быть употреблено во множественном числе (заказчиков). Ведь на самом деле речь идёт о разных возможных заказчиках, в связи с чем противопоставление единственного и множественного числа при их обозначении оказывается нерелевантным.

6. Значение адвербиалов тайно, втайне в первом приближении может быть описано посредством глагольного предиката скрывать $(X, P, y)$, имеющего по крайней мере три семантических актанта:

$\mathrm{X}$ - субъект утаивания;

P - ситуация, которая скрывается субъектом;

$\mathrm{У}$ - адресат (лицо или множество лиц), от которого $\mathrm{X}$ скрывает $\mathrm{P}$.

Таким образом, $X$ скрывает $P$ от $У$-ка $\approx$ ' $\mathrm{X}$ каузирует то, что У не знает, что имеет место Р'. При этом имеется в виду, что У - это единоличный или коллективный участник, для которого небезразлично наличие или отсутствие ситуации Р. Субъект Х прилагает усилия к тому, чтобы У не узнал о Р, поскольку осведомлённость У-ка о реальном положении дел нежелательна для X-a - например, она может воспрепятствовать достижению той или иной его цели.

Важно отметить, что адресатная валентность, указывающая на участника У, является синтаксически факультативной. т.е. в терминах классификации валентностей, предложенных в (Апресян 1974) квалифицируется как сильная семантическая и слабая синтаксическая. Если нереализация адресатной валентности не выполняет анафорическую функцию, т.е. не указывает на ранее названного участника У, то обычно имеется в виду, что У представляет собой множество лиц.

Значение рассматриваемых адвербиалов соотносится с такими употреблениями глагола скрывать, которые предусматривают, что:

a) субъект $\mathrm{X}$ является обязательным участником утаиваемой ситуации $\mathrm{P}$;

б) субъект $\mathrm{X}$ прилагает усилия к тому, чтобы У не узнал о Р в течение всего времени существования $\mathrm{P}$.

Легко видеть, что значение скрывать не имеет таких ограничений - ср. Иван скрыл от Петра, что приехала Анна, где имеется в виду. что Иван не совпадает с участником утаиваемой ситуации и что он не даёт возможности Петру узнать о приезде Анны уже после того, как этот приезд состоялся.

Таким образом, имплицитные видовые значения рассматриваемых адвербиалов определяются видовыми значениями, которые в разных контекстах принимает имплицитный глагол скрывать. Эти видовые значения в свою очередь
К проблеме выявления видовых глагольных значений.

71

коррелируют с видовой формой и семантическим типом предиката сказуемого, обозначающего ситуацию Р. Рассмотрим ряд примеров:

(26) а. Король обратился к матери и тайно отвёл её в комнату, которую запер за собою (И.А. Анненский, НКРЯ); б. Он даже рискнул тайно прилететь в Москву, чтобы встретиться со Светланой (НКРЯ); в. Она в тот же миг выходит тайно из дворца петергофского, садится в простую коляску и господами Орловыми с величайшею поспешностию отвозится в Петербург (А.Т. Болотов, НКРЯ).

В примерах (26) имплицитно реализовано событийное значение СВ cкpывать, указывающее на завершённый однократный процесс утаивания, синхронный завершённому действию, обозначенному сказуемым. При этом имеется виду, что благодаря дополнительным усилиям субъекта заинтересованный адресат У не знал ни о действии Р (король отвёл мать в комнату, субъект прилетел в Москву), ни о ситуации, ставшей её результатом (т.е. У не знал, что мать находится в комнате (26а), а субъект - в Москве (26б)). Аналогичным образом в (26в), где однородные сказуемые употреблены в форме настоящего исторического НСВ, имеется в виду, что никто из заинтересованных лиц У не видел, как Екатерина вышла из дворца, затем села в простую карету и т.д., и поэтому пребывают в уверенности, что она продолжает находиться во дворце.

(27) а. Я его с детства знаю, девчонкой даже была в него тайно влюблена; б.Был бы у него другой характер, Каринка, наверное, до сих пор тайно вздыхала бы по нему (А. Маринина, НКРЯ); в) А мне понравился Генка Шестопалов, тихоня интеллектуал, видно, парень начитанный, порядочный и тайно влюблён в Риту Черкасову (коллективный Форум, НКРЯ); г) Тайно грело Сторожева и то, что он был для Наташи благодетелем...(А.Слаповский, НКРЯ); д) Колюня имени своего не любил, втайне мечтая его поменять и назваться, например, Виктором или Алексеем (А.Варламов, НКРЯ); е) Она ... охотно даже согласилась с предложением братьев, имея втайне от них матримониальные цели (А. Азольский, НКРЯ).

В приведенных примерах имплицитные формы НСВ скрывать реализованы в значении занятия, занимающего «сверхдолгий интервал, не целиком заполненный деятельностью или действиями субъекта, но при этом характеризующий его на всём протяжении этого интервала» (Падучева 1996: 149). Речь идёт о том, что усилия, прилагаемые субъектом, направлены на то, чтобы никто не узнал о его эмоционально-психологическом состоянии влюблённости (27а,б,в), состоянии удовлетворённости от осознания своего благодетельства (27г), о мечтах поменять своё имя (27д), о целеполагании (27e). При этом усилия субъекта прилагаются столько же времени, сколько длится соответствующее состояние.

(28) а. Во времена фараонов по этим маршрутам тайно передвигались контрабандисты (А. Волков, НКРЯ); б. Я потом долго. почти год, буду слышать его весёлый голос, он станет часто звонить из своего детского дома, тайно проникая по вечерам в директорский кабинет (А. Моторов, НКРЯ); в. Прежде ... цензоры покидали мир втайне, как разведчики или главные инженеры военных заводов...(А. Варламов, НКРЯ); г. Тома разведала, что у Василисы есть своя особая еда: в чулане у неё хранился сушёный белый хлеб, нарезанный мелкими кусочками, и Василиса ела его по утрам от всех втайне (Л. Улицкая, НКРЯ) 
В примерах (28а - 28г) имплицитные формы НСВ скрывать употреблены в итеративном значении, указывающем на многократные утаивания контрабандистами своих периодических передвижений (28a), многократных проникновений героя в директорский кабинет (28б). В (28в) упоминаются времена, когда не названные полномочные органы скрывали от общественности смерти цензоров, подобно тому, как не сообщали о смерти разведчиков или главных инженеров военных заводов. В (28г) говорится о постоянных сокрытиях Василисой своих утренних трапез.

(29) Все, кто видел Пушкина вечером 26 января на балу у графини Разумовской, где он втайне подыскивал себе секунданта, поражались его весёлости, блистательности, лёгкости (В. Отрощенко, НКРЯ)

В последнем примере имплицитный глагол НСВ скрывать употреблён в актуально-длительном значении, поскольку именно это значение НСВ реализует глагольное сказуемое подыскивал второго придаточного предложения. Имеется в виду, что весёлость, блистательность, лёгкость помогли Пушкину скрыть его поиски. Примечательно, что актуально-длительное значение никогда не возникает при эксплицитном употреблении форм НСВ глагола скрывать в поверхностной структуре.

8. Одним из производных глагола искать является адвербиальный оборот 6 nоисках. Он примыкает к группе сказуемого, указывающей на действия, которые предпринимает субъект поиска для того, чтобы найти искомый объект. Тем самым группа сказуемого заполняет такую переменную в значении искать, которая всегда остаётся незаполненной при употреблении самого глагола. Ведь при нём могут быть нормативно реализованы только две валентности - субъекта поиска и его объекта, обозначенного прямым дополнением. Но на самом деле в толковании искать присутствует по крайней мере четыре переменных, указывающих на субъекта поиска (X), его объекта (У), конкретные шаги, предпринимаемые субъектом (P) и критерий отбора $(Z)$, необходимый для обнаружения искомого объекта. Употребление обстоятельственного оборота в поисках позволяет конкретизировать три первые переменные - ср. примеры из НКРЯ, в которых данный адвербиал фигурирует в прямом, неметафорическом значении (в отличие от оборотов типа в поисках решения (истины, радостей, смысла жизни...)):

(30) а. Во время той прогулки он то и дело заходил в магазинчики в поисках фляжки для виски ... для любимой жены; б. Мы колесили по городу в поисках подходящей квартирки; в. Он стал шарить по столу в поисках сигарет (НКРЯ])

Валентность критерия отбора может быть заполнена преимущественно нестандартно (не в соответствии с моделью управления глагола) с помощью прилагательного или причастного оборота при существительном, обозначающем искомый объект - cp. косвенное обозначение данной валентности прилагательным подходящую в примере (30б).

На более глубоком уровне представления подобные фразы интерпретируются с помощью целевой конструкции.

Так, (30б) ₹ 'Мы колесили по городу чтобы найти подходящую квартирку'.

Таким образом, во фразах с адвербиалом в поисках (как и с глаголом искать) всегда имплицитно присутствует инфинитивная форма СВ найти (= 'обнаружить и получить доступ’) в событийном значении.
II. Глагольное сказуемое заполняет валентность адвербиала, который семантически не связан с конкретным глагольным предикатом, но сам является самостоятельным полноценным предикатом, имеющим достаточно абстрактное значение. Это значение указывает на некоторое общее свойство, присущее всем ситуациям, описываемым любым глагольным сказуемым. Между тем во всех ранее рассмотренных примерах семантическая функция адвербиала была другой - при его «посредничестве» предикат глагольного сказуемого опосредованно заполнял валентность предиката, семантическим производным которого является адвербиал.

1. В частности, представляют интерес наречия, отражающие темпоральные характеристики описываемых ситуаций. Характеризуя ситуацию, выражаемую сказуемым, они способны влиять на видовую форму глагола, в ряде случаев предписывая использование только одной из видовых форм. Как известно, существует немало наречий, так или иначе указывающих на частоту осуществления однотипных ситуаций - ср. часто, нередко, изредка, иногда, постоянно, время от времени, неизменно... Они однозначно требуют использования глагольных форм НСВ в итеративном значении и абсолютно несовместимы с формами СВ: *часто (изредка, постоянно ...) уехал; *иногда (время от времени, не изменно...) уехал ...

Интересно, что в отличие от перечисленных адвербиалов такие наречия как не раз, много раз, неоднократно, многократно не сочетаются с глагольными формами НСВ настоящего времени:

(31) *Он не раз (много раз, неоднократно, многократно) сюда приходит.

Между тем они, как и другие аналогичные адвербиалы, безукоризненно сочетаются с такими глаголами в прошедшем и будущем:

(32) Он не раз (много раз, неоднократно, многократно) сюда приходил (будет приходить).

Как представляется, аномальность (31) объясняется тем, что в отличие от выше перечисленных наречий, адвербиалы, фигурирующие в (31), обозначают заведомо конечное число - число однотипных случаев (здесь - приходов), которые имели место в прошлом или будут иметь место в будущем. Между тем употребление итеративного глагола в форме НСВ настоящего времени нормативно указывает не только на события, которые входят во время говорящего (Апресян 1986) со стороны прошлого, возможно, имеют место в момент речевого акта, но также и те, которые могут или будут повторяться в будущем, не выходящем за пределы времени говорящего. Такое количество однотипных ситуаций, воспринимается как довольно размытое, неопределённое и не может считаться конечным, как это предусмотрено значениями адвербиалов в (31). Таким образом, (31) содержит в себе противоречие, которое и объясняет его аномальность. А в (32) такое противоречие отсутствует, так как в нём речь идёт о конечном количестве однотипных событий, которые происходили только в прошлом или будут происходить только в будущем.

Примечательно и то, что при употреблении некоторых из этих адвербиалов в контексте будущего времени наряду с глагольными формами НСВ вполне употребимы параллельные формы CB:

Славистика XXIII/1 (2019) 
(33) Он не раз (много раз, неоднократно) будет сюда приходить $=$ Он не раз (много раз, неоднократно) сюда придёт.

В то же время в прошедшем времени о такой эквивалентности не может быть и речи:

(34) Он не раз (много раз, неоднократно) сюда приходил, но *Он не раз (много раз, неоднократно) сюда пришёл.

Как видим, при употреблении в этих контекстах форм СВ глаголов направленного передвижения в будущем времени данные глаголы приобретают, подобно параллельным формам НСВ, свойство двунаправленности. А в прошедшем времени этого не происходит. Ведь форма СВ прош. пришёл указывает на достижение состояния (здесь - локализации субъекта он в месте, о котором идёт речь), которое продолжает сохраняться в обсуждаемом временном отрезке, т.е. он (ещё) не ушёл.

2. Рассмотрим далее ряд наречий, так или иначе отражающих скорость и сроки протекания описываемых действий или процессов. Как было показано в работе (Богуславский, Иомдин 2000), вокабула БЫСТРО содержит две лексемЫ - БЫСТРО 1 'с большой скоростью’ и БЫСТРО 2 'за короткий срок'. В то же время вокабула МЕДЛЕННО состоит из одной лексемы МЕДЛЕННО 'с малой скоростью’ - ср. толкование, сопоставленное в цитируемой работе данному наречию:

Медленно $X$-овать $\approx$ 'последовательные фазы процесса или действия $\mathrm{X}$ следуют друг за другом через большие промежутки времени’.

Прототипическими контекстами БЫСТРО 1 и МЕДЛЕННО являются конструкции с глаголами НСВ.

В сочетании с глагольными формами НСВ прошедшего времени, обозначающими процессуальные действия или процессы, наречия медленно, быстро характеризуют соответствующий процесс «изнутри» (т.е. согласно синхронной временной позиции наблюдателя (Падучева 1997: 256)), указывая соответственно на низкую или высокую скорость его протекания:

(35) Он медленно (быстро) шёл; Он медленно (быстро) перебирал клавиши; Чайник медленно (быстро) закипал

В сочетании с итеративным глаголом в настоящем времени эти же наречия указывают на свойство:

(36) Он медленно (быстро) ходит; Он быстро читает с листа (как позитивная характеристика профессионального музыканта); Электрические чайники медленно закипают.

Прототипическими контекстами для БЫСТРО 2 служат конструкции с глаголами СВ. БЫСТРО 2 указывает на короткий срок, за который завершённое действие или процесс достигли цели или предела (т.е. в соответствии с ретроспективной позицией наблюдателя (Падучева 1997: 256)). При этом глагольные формы СВ имеют событийное значение завершённого действия или процесса:

(37) Он быстро оделся; Иван быстро доехал до центра; Чайник быстро закипел.

Аналогичную функцию выполняет и наречие мгновенно, указывающее на сверхкороткий срок:
К проблеме выявления видовых глагольныхх значений.

(38) Он встретил ... беспомощный взгляд триумфатора и мгновенно сообразил, что надо пощадить народного избранника (НКРЯ),

где речь идёт о сверхкратком сроке получения ментального результата мыслительного процесса.

В сочетании с глагольными формами НСВ настоящего времени мгновенно представляет сверхскоростное достижение предела или результата как свойство субъекта. Сp. (39), где этот эффект возникает благодаря сочетанию мгновенно с формой НСВ ментального предиката настоящего времени с заблокированной пропозициональной валентностью:

(39) Он мгновенно соображает.

Данные конструкции могут использоваться и для обозначения событий, происшедших через короткий или минимальный интервал после точки отсчёта:

(40) Скорая помощь» быстро приехала;

(41) Когда началась гитлеровская агрессия в Европе, Дания мгновенно капитулировала (НКРЯ)

Подобная интерпретация возникает тогда, когда точка отсчёта так или иначе выражена. В (40) она подразумевается - ведь скорая помощь может приехать только после её вызова. А в (41) точка отсчёта эксплицирована указанием на начало гитлеровской агрессии в Европе.

Подобно тому, как с лексемой БЫСТРО 1 соотносится лексема БЫСТРО 2, с наречием МЕДЛЕННО соотносится наречие ДОЛГО, которое как и МЕДЛЕННО, сочетается лишь с глагольными формами НСВ. Как и БЫСТРО 2, ДОЛГО характеризуе завершённый процесс или действие, указывая однако на их длительное протекание:

(42) Чайник долго закипал; Он долго брился.

Но в отличие от МЕДЛЕННО, ДОЛГО может характеризовать также прекратившиеся состояния и однородные неквантованные действия или процессы:

(43) Она долго сидела у окна; Квартира долго пользовалась странной репутацией; Он долго бродил по улицам.

Конструкции типа ДОЛГО НЕ Р описывают специфику постепенного наступления ожидаемой желательной ситуации Р. При этом фиксируется некоторое отклонение от нормы - срок, реально потребовавшийся для наступления $\mathrm{P}$, превысил временной интервал, который согласно определённым общепринятым представлениям нормативно достаточен для наступления Р. На глубинном уровне такие структуры естественно интерпретировать посредством конструкции с противопоставительным отрицанием:

(44) Скорая помощь долго не приезжала; Он долго не звонил $\approx$ 'Скорая помощь приехала (Он позвонил) не через нормативно ожидаемый временной интервал, а через интервал, существенно больший нормативного'

Существенно, что на глубинном уровне поверхностным формам НСВ (не приезжала, не звонил) соответствуют утвердительные формы СВ в событийном значении - 'приехала', 'позвонил'.

Аналогичным образом интерпретируются предложения, описывающие достижение желательного Р как результата немонотонных процессов, содержащих 
латентный период (Богуславский, Иомдин 2000), который предшествует реально наблюдаемым изменениям, ведущим к Р. Примечательно, что утвердительные и отрицательные предложения с предикатами, обозначающими такие процессы, квазисинонимичны - ср. (В. Апресян, Шмелёв 2018). Так, фраза (45a) Чайник долго закипал прагматически эквивалентна (45б) Чайник долго не закипал. Но на семантическом уровне между ними можно увидеть некоторое различие:

$(45 a) \approx$ 'Чайник закипел не через нормативно ожидаемый временной интервал, а через интервал. существенно больший нормативного', тогда как

$(456) \approx$ 'Чайник начал кипеть не через нормативно ожидаемый временной интервал, а через интервал, существенно больший нормативного'.

Как видим, в (45a) и (45б) речь идёт о разных реальных и нормативных временных интервалах. В (45a) имеются в виду интервалы, которые охватывают весь процесс закипания чайника, а в (45б) - интервалы, которые охватывают только латентный, подготовительный период этого процесса.

Разумеется, можно привести ещё немало свидетельств нетривиального взаимодействия адвербиалов с аспектуальными свойствами глагольных предикатов В то же время представляется, что и рассмотренный материал служит достаточным аргументом в пользу дальнейших исследований подобных взаимодействий.

\section{Использованная литература}

Апресян, Валентина Ю., Шмелев, Алексей Д. Парадокс долго (не) закипающего чайника // La relation temps / aspect: approches typologique et contrastive. Tatiana Milliaressi (Éd.) Université Charles-de-Gaulle - Lille 3. Collection UL3 Travaux et Recherches, Р. $419-423,2018$.

Апресян, Юрий Д. Лексическая семантика. Синонимические средства языка. М.: Наука, 1974.

Апресян, Юрий Д. Дейксис в лексике и грамматике и наивная модель мира [В:] Семиотика и информатика. - М., - Вып. 28. - С. 5-33, 1986.

Богуславский, Игорь М. Сфера действия лексических единиц. - М.: Школа «Языки русской культуры», 1996.

Богуславский, Игорь М. Между истиной и ложью: адвербиалы в контексте снятой утвердительности [В:]

Логический анализ языка. Между ложью и фантазией. Отв. ред. Н.Д.Арутюнова М: Издательство «Индрик», С. 67 - 77, 2008.

Богуславский, Игорь М., Иомдин, Леонид Л. Семантика медленности [В:] Слово в тексте и в словаре. Сборник статей к семидесятилетию академика Ю.Д. Апресяна. Иомдин Л.Л., Крысин Л.П. (ред.). М.: С. $52-60,2000$.

Булыгина, Татьяна В. К построению типологии предикатов в русском языке [В:] Семантические типы предикатов. - М., 1982.

Жолковский Александр, К., Мельчук Игорь, А. О семантическом синтезе [В:] Проблемы кибернетики. Вып. N 19.- М., Наука. - С. 177 - 238, 1967.

Падучева Елена, В. Семантические исследования: Семантика времени и вида в русском языке. Семантика нарратива. - М.: Языки русской культуры, 1996. -464 стр.
К проблеме выявления видовых глагольных значений.

Падучева Елена, В. Давно и долго // Логический анализ языка. Язык и время. Отв. ред. Н.Д. Арутюнова, Т.Е.Янко. - М.: Издательство «Индрик», С. 253 -266, 1997.

Пчелинцева Елена, Э. От глагола к имени: аспектуальность в русских, украинских и польских именах действия. - Санкт-Петербург:: «НАУКА», 2016.

Труб Владимир, М. К проблеме интерпретации видовой характеристики отглагольных существительных [B:]

Аспектуальная семантическая зона: типология систем и сценарии диахронического развития. Сборник статей V Международной конференции по аспектологии Международного комитета славистов. Киото, 13 - 15 ноября 2015 г, С. $299-306$.

Храковский Виктор, С. Реализует ли категория вида идею времени? // La relation temps / aspect: approches typologique et contrastive. Tatiana Milliaressi (Éd.) Université Charles-de-Gaulle - Lille 3. Collection UL3 Travaux et Recherches, P.181 $-185,2018$.

Владимир Труб

О ПРОБЛЕМУ ИДЕНТИФИКАЦИЈЕ АСПЕКТУАЛНИХ СВОЈСТАВА АДВЕРБИЈАЛА

Резиме

Рад је заснован на претпоставци да је широки спектар видских значења свршеног и несвршеног вида (СВ и НСВ) својствен не само глаголима (и, шире гледано, вербоидима), као прототипским носиоцима аспектуалних значења, већ да на ова значења посредно може указивати и низ невербоидних врста речи, које не поседују никакве формалне аспектуалне показатеље. Истовремено, значење многих од њих посредно је везано за предикате, који с прототипично изражавају глаголима. У оваква неглаголска језичка средства - носиоце импликативних аспектуалних значења - спадају, између осталог, адвербијали - прилози или групе настале спајањем предлога или везника с именицама.

На нивоу синтаксичке структуре реченице адвербијал, који стоји уз глагол, посматра се као јединица која је у зависном односу према глаголу. С друге стране, с тачке гледишта локичко-семантичке репрезентије фразе глаг на неки начин допуе , с тание лледишта лораленију адвербијра, олносно ватенију која се допушава речју према којој је алвербија валенциу адвербијала, односно валенцију која се допуњава речју према којој је адвербија. у синтаксички зависном односу, вршећи тиме улогу његовог семантичког актанта. У раду се проучавају различити типови аспектуални

I. Адвербијал представља алтернативно средство реализације неког глаголског предиката. У оваквим ситуацијама задатак анализе се своди на идентификацију видског значења глагола који се „маскирао“ као адвербијал. С тим у вези потребно је трансформисати анализирану фразу у такав њој синонимичан израз у којем би дати глаголски предикат био представљен експлицитно. Тражено видско значење суштински зависи од семантичког типа предикат који јој одговара, као и од видског облика глаголског предиката.

Као што следи из анализиране грађе, одређени адвербијали могу попуњавати и такве валенцијске позиције глаголског предиката који се корелише са адвербијалом које не могу бити предвидљиве полазећи од стандардног рекцијског модела одговарајућег глагола у предикату.

Показано је да адвербијали као изведене јединице могу представити најразличитија видска значења њима одговарајућих глагола - актуално-трајно и процесно значење НСВ, хабитуално, значење стања и активности НСВ, као и значење достигнућа СВ. Притом адвербијали 
могу указивати и на таква аспектуална значења која не могу бити изражена одговарајућим глаголима у предикату.

II. Глаголски предикат допуњује валенцију адвербијала који семантички није везан за конкретни глаголски предикат, али саิм јесте предикат вишег реда у односу на глаголски предикат, те има прилично апстрактно значење. Овде су интересантни прилози који одражавају темпоралне карактеристике описиваних ситуација. Карактеришући ситуацију изражену глаголским предикатом, они су способни да утичу на видски облик глагола, у низу случајева захтевајући коришћење само једног видског облика. У раду је анализиран низ прилога који на овај или онај начин указују на учесталост реализације ситуација које припадају истом типу. Они недвосмислено захтевају коришћење глаголских облика НСВ у итеративном значењу и апсолутно су неспојиви с облицима СВ. У оквиру прилога овог типа издваја се подгрупа средстава која, за разлику од других елемената одговарајуће групе, нису спојива с глаголима НСВ у облику презента. У раду је дато објашњење ове појаве.

Анализиране су такође и семантичке функције прилога који одражавају брзину и дужину вршења описиваних радњи и процеса.

У целини рад оправдава актуелност будућих истраживања аспектуалних својстава адвербијала.

Кључне речи: свршени вид, несвршени вид, адвербијал, валенција, глагол, предикат, видско значење, актуелно-трајно значење, итеративно значење, значење достигнућа. 